\title{
Mitochondria Buffer Physiological Calcium Loads in Cultured Rat Dorsal Root Ganglion Neurons
}

\author{
John L. Werth and Stanley A. Thayer \\ Department of Pharmacology, University of Minnesota Medical School, Minneapolis, Minnesota 55455
}

We sought to determine whether low-affinity, high-capacity mitochondrial $\mathrm{Ca}^{2+}$ uptake contributes to buffering physiological $\mathrm{Ca}^{2+}$ loads in sensory neurons. Intracellular free calcium concentration $\left(\left[\mathrm{Ca}^{2+}\right]_{)}\right)$and intracellular free hydrogen ion concentration $\left(\left[\mathrm{H}^{+}\right]_{i}\right)$ were measured in single rat dorsal root ganglion (DRG) neurons grown in primary culture using indo-1 and carboxy-SNARF-based dual emission microfluorimetry. Field potential stimulation evoked action potential-mediated increases in $\left[\mathrm{Ca}^{2+}\right]$. Brief trains of action potentials elicited $\left[\mathrm{Ca}^{2+}\right]_{i}$ transients that recovered to basal levels by a single exponential process. Trains of $>25$ action potentials elicited larger increases in $\left[\mathrm{Ca}^{2+}\right]$, recovery from which consisted of three distinct phases. During a rapid initial phase $\left[\mathrm{Ca}^{2+}\right]_{1}$ decreased to a plateau level (450-550 nM). The plateau was followed by a slow return to basal $\left[\mathrm{Ca}^{2+}\right]_{r}$

$\left[\mathrm{Ca}^{2+}\right]_{i}$ transients elicited by $40-50$ action potentials in the presence of the mitochondrial uncoupler carbonyl cyanide chlorophenyl hydrazone (CCCP), or the electron transport inhibitor antimycin A1, lacked the plateau, and the recovery to basal $\left[\mathrm{Ca}^{2+}\right]_{i}$ consisted of a single slow phase. Depolarization with $50 \mathrm{~mm} \mathrm{~K} \mathrm{~K}^{+}$produced a multiphasic $\left[\mathrm{Ca}^{2+}\right]_{\text {i }}$ transient and increased $\left[\mathrm{H}^{+}\right]$, from $74 \pm 3$ to $107 \pm 8 \mathrm{~nm}$. The rise in $\left[\mathrm{H}^{+}\right]$, was dependent upon extracellular $\mathrm{Ca}^{2+}$ and was inhibited by mitochondrial poisons. With mitochondrial $\mathrm{Ca}^{2+}$ buffering pharmacologically blocked, the recovery to basal $\left[\mathrm{Ca}^{2+}\right]_{i}$ was unaffected by removal of extracellular $\mathrm{Na}^{+}$.

We conclude that large $\mathrm{Ca}^{2+}$ loads are initially buffered by fast mitochondrial sequestration that effectively uncouples electron transport from ATP synthesis, leading to an increase in $\left[\mathrm{H}^{+}\right]_{\text {r }}$ Small $\mathrm{Ca}^{2+}$ loads are buffered by a nonmitochondrial, $\mathrm{Na}^{+}$-independent process.

[Key words: intracellular calcium, intracellular $\mathrm{pH}$, mitochondria, sensory neuron, action potentials, metabolism]

Increases in $\left[\mathrm{Ca}^{2+}\right]$, activate a number of neuronal signaling processes (Miller, 1988) and, when excessive, may underlie neurodegenerative processes (Choi, 1987; Randall and Thayer, 1992). $\left[\mathrm{Ca}^{2+}\right]$, increases in response to $\mathrm{Ca}^{2+}$ influx through voltage-gated (Tsien, 1983; Hess, 1990) and receptor-gated calcium channels (MacDermott et al., 1986) as well as $\mathrm{Ca}^{2+}$ release from

\footnotetext{
Received Jan. 11, 1993; revised July 5, 1993; accepted July 13, 1993.

This work was supported by grants from NIH (DA06781 and DA07304) and the NSF (BNS9010486). S.A.T. is a University of Minnesota McKnight-Land Grant Professor. J.L.W was supported by NIDA Training Grant T32DA07097.

Correspondence should be addressed to Dr. S. A. Thayer, Department of Pharmacology, University of Minnesota Medical School, 3-249 Millard Hall, 435 Delaware Street, S.E., Minneapolis, MN 55455.
}

Copyright (C) 1994 Society for Neuroscience $0270-6474 / 94 / 140348-09 \$ 05.00 / 0$ intracellular stores (Henzi and MacDermott, 1992). Multiple mechanisms exist to remove $\mathrm{Ca}^{2+}$ from the cytosol (reviewed in Carafoli, 1987; Miller, 1991); they are (1) mitochondrial $\mathrm{Ca}^{2+}$ buffering (Thayer and Miller, 1990), (2) $\mathrm{Ca}^{2+}$ binding by cytosolic proteins (Baimbridge et al., 1992), (3) ATP-dependent $\mathrm{Ca}^{2+}$ efflux or sequestration (Carafoli, 1991; Lytton et al., 1991; Benham et al., 1992), and (4) $\mathrm{Ca}^{2+}$ efflux via $\mathrm{Na}^{+} / \mathrm{Ca}^{2+}$ exchange (Sanchez-Armass and Blaustein, 1987; Blaustein et al., 1991). The relative contributions of each of these processes to $\mathrm{Ca}^{2+}$ buffering in neurons are unclear.

In rat sensory neurons, mitochondria appear to play a prom-

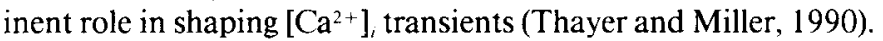
Studies with isolated mitochondria indicate that they have a tremendous capacity to sequester $\mathrm{Ca}^{2+} \cdot \mathrm{Ca}^{2+}$ uptake by mitochondria must be considered in the context of the chemiosmotic hypothesis (Nicholls, 1985). The respiratory chain utilizes the energy made available from electron transport to pump protons out of the mitochondrial matrix. This results in an electrochemical gradient across the inner mitochondrial membrane. Under resting conditions, ATP is generated by reentry of protons into the mitochondrial matrix through the ATP synthase. When faced with a large $\mathrm{Ca}^{2}+$ load, mitochondria take up $\mathrm{Ca}^{2+}$ via a uniporter that employs this large electrochemical potential to drive $\mathrm{Ca}^{2+}$ across the inner mitochondrial membrane. $\mathrm{Ca}^{2+}$ uptake takes place in lieu of $\mathrm{H}^{+}$uptake and ATP synthesis while electron transport continues in order to maintain the electrochemical gradient (Nicholls, 1985; Gunter and Pfeiffer, 1990). $\mathrm{Ca}^{2+}$ exits the mitochondria via $\mathrm{Na}^{+} / \mathrm{Ca}^{2+}$ exchange or by an $\mathrm{Na}^{+}-$ independent mechanism that is yet to be fully characterized (Gunter and Pfeiffer, 1990). A steady state between $\mathrm{Ca}^{2+}$ uptake into and efflux from mitochondria is eventually reached. The $\left[\mathrm{Ca}^{2+}\right]_{i}$ at which the steady state is reached is termed the "set point." The set point has been found to be on the order of 0.5 $1 \mu \mathrm{M}$ in isolated mitochondria (Carafoli, 1987). This relatively high set point has led to the generally held belief that mitochondria contribute to $\mathrm{Ca}^{2+}$ buffering only under the pathological conditions of $\mathrm{Ca}^{2+}$ overload. However, in excitable cells $\left[\mathrm{Ca}^{2+}\right]_{i}$ will reach micromolar levels during intense stimulation. Additionally, the mitochondrial set point in intact cells may be lower than that observed in isolated mitochondria, raising the possibility that mitochondria may transiently sequester $\mathrm{Ca}^{2+}$ during electrical activity. Indeed, it has been suggested that intramitochondrial $\mathrm{Ca}^{2+}$ serves as a means to couple energy demands to ATP production (McCormack et al., 1990). Mitochondria isolated from rat brain have been shown to take up $\mathrm{Ca}^{2+}$ at physiologically relevant $\mathrm{Ca}^{2+}$ concentrations (Jensen et al., 1987; Rottenberg and Marbach, 1990). Recently, increases in intramitochondrial $\mathrm{Ca}^{2+}$ concentration were demonstrated in 
bovine epithelial cells following a modest $\left[\mathrm{Ca}^{2+}\right]_{i}$ increase in duced by ATP (Rizzuto et al., 1992).

In light of evidence suggesting that mitochondria will sequester $\mathrm{Ca}^{2+}$ at physiologically relevant concentrations, and the pronounced contribution by mitochondria to shaping $\left[\mathrm{Ca}^{2+}\right]$, transients in dorsal root ganglion (DRG) neurons, we sought to test the hypothesis that mitochondria contribute to $\left[\mathrm{Ca}^{2+}\right]_{i}$ regulation in intact rat DRG neurons during physiological stimuli. We describe the role of mitochondria in buffering physiological $\mathrm{Ca}^{2+}$ loads and their contribution to the concomitant acidification that results from $\mathrm{Ca}^{2+}$ influx.

Portions of this work have appeared in abstract form (Werth and Thayer, 1992).

\section{Materials and Methods}

Cell culture. Neurons from the DRG were grown in primary culture as previously described (Thayer and Miller, 1990). Briefly, the DRG from 1-3-d-old Sprague-Dawley rats were dissected from the thoracic and lumbar regions and incubated at $37^{\circ} \mathrm{C}$ in collagenase-dispase $(0.8$ and $6.4 \mathrm{U} / \mathrm{ml}$, respectively) for $20-30 \mathrm{~min}$. Ganglia were dissociated into single cells by trituration through a flame-constricted pipette. Cells were plated onto laminin-coated glass coverslips ( $25 \mathrm{~mm}$ round) that had been derivatized (Weetall, 1970). For derivatization, coverslips were refluxed $4-8 \mathrm{hr}$ in $10 \% 3$-aminopropyltriethoxysilane in toluene, rinsed with toluene, and dried. Coverslips were then treated for $30 \mathrm{~min}$ with $2 \%$ glutaraldehyde, coated with polyornithine, and finally treated in 50 $\mu \mathrm{g} / \mathrm{ml}$ laminin overnight. Cells were grown in Ham's F12 media supplemented with $5 \%$ heat-inactivated rat serum, $50 \mathrm{ng} / \mathrm{ml}$ nerve growth factor, $44 \mathrm{~mm}$ glucose, $2 \mathrm{~mm}$ L-glutamine, minimum essential medium (MEM) vitamins, and penicillin/streptomycin $(100 \mathrm{~J} / \mathrm{ml}$ and $100 \mu \mathrm{g} /$ $\mathrm{ml}$, respectively). Cultures were maintained at $37^{\circ} \mathrm{C}$ in a humidified atmosphere of $5 \% \mathrm{CO}_{2}$. Cells were used 4-9 d after plating.

$\left[\mathrm{Ca}^{2+}\right]_{\mathrm{i}}$ measurement. $\left[\mathrm{Ca}^{2+}\right]_{\text {, was determined using a microfluorime- }}$ ter to monitor the $\mathrm{Ca}^{2+}$-sensitive fluorescent chelator indo-1 (Grynkiewicz et al., 1985). For excitation of the indo-1, the light from a 75 $W$ Xe arc lamp was passed through a $350 \pm 10 \mathrm{~mm}$ band-pass filter (Omega Optical, Brattleboro, VT). Excitation light was reflected off of a dichroic mirror $(380 \mathrm{~nm})$ and through a $70 \times$ phase-contrast oil immersion objective (Leitz, NA 1.15). Emitted light was sequentially reflected off of dichroic mirrors (440 and $516 \mathrm{~nm}$ ) through band-pass filters $(405 \pm 20$ and $495 \pm 20 \mathrm{~nm}$, respectively) to photomultiplier tubes operating in photon counting mode (Thorn EMI, Fairfield, NJ). Cells were illuminated with transmitted light (580 $\mathrm{nm}$ long-pass) and visualized with a video camera placed after the second emission dichroic. Recordings were defined spatially with a rectangular diaphragm. The TTL photomultiplier output was integrated by passing the signal through an 8-pole Bessel filter at $2.5 \mathrm{~Hz}$. This signal was then input into two channels of an analog-to-digital converter (Indec Systems, Sunnyvale, CA) sampling at either 1 or $10 \mathrm{~Hz}$.

Cells were loaded with indo-1 by incubation in $2 \mu \mathrm{m}$ indo- 1 acetoxymethyl ester (Molecular Probes Inc., Eugene, OR) for $45 \mathrm{~min}$ at $37^{\circ} \mathrm{C}$ in HEPES-buffered Hank's balanced salt solution (HHSS), pH 7.45, containing $0.5 \%$ bovine serum albumin. HHSS was composed of the following (in mM): HEPES, $20 ; \mathrm{NaCl}, 137 ; \mathrm{CaCl}_{2}, 1.3 ; \mathrm{MgSO}_{4}, 0.4$; $\mathrm{MgCl}, 0.5 ; \mathrm{KCl}, 5.4 ; \mathrm{KH}_{2} \mathrm{PO}_{4}, 0.4 ; \mathrm{NaHPO}_{4}, 0.3 ; \mathrm{NaHCO}_{3}, 3.0$; and glucose, 5.6. Loaded cells were mounted in a flow-through chamber for viewing (Thayer et al., 1988). The superfusion chamber was mounted on an inverted microscope and cells were superfused with HHSS at a rate of $1-2 \mathrm{ml} / \mathrm{min}$ for $15 \mathrm{~min}$ prior to starting an experiment. A suitable cell, defined as a rounded cell body that had extended fine processes and was isolated from other cells, was localized by phase-contrast illumination. $\left[\mathrm{Ca}^{2+}\right]$, transients were elicited either by superfusion for 30 sec with $50 \mathrm{~mm} \mathrm{~K} \mathrm{~K}^{+}\left(\mathrm{K}^{+}\right.$was exchanged for $\mathrm{Na}^{+}$reciprocally) or by evoking action potentials with field potential stimulation (Sipahimalani et al., 1992). Field potentials were generated by passing current between two platinum electrodes by means of a Grass S44 electrical stimulator and a stimulus isolation unit (Quincy, MA). Similar results were seen whether capacitative or direct pulses were delivered. Trains of 5-50 1 msec pulses were delivered at a rate of $10 \mathrm{~Hz}$. Stimulus voltage required to elicit action potentials varied for each individual cell. The threshold voltage for a cell was determined prior to beginning an experiment and subsequent stimuli were $20 \mathrm{~V}$ over this threshold. Cells were stimulated in this manner once every $4 \mathrm{~min}$.

After completion of each experiment, the microscope stage was adjusted so that no cells or debris occupied the field of view defined by the diaphragm, and then background light levels were determined (typically less than $5 \%$ of cell counts). Autofluorescence from cells that had not been loaded with the dye was not detectable. Records were later corrected for background and the ratios recalculated. Ratios were converted to $\left[\mathrm{Ca}^{2+}\right]_{i}$ by the equation $\left[\mathrm{Ca}^{2+}\right]_{i}=K_{D} \beta\left(R-R_{\min }\right) /\left(R_{\max }-R\right)$, in which $R$ is the $405: 495 \mathrm{~nm}$ fluorescence ratio (Grynkiewicz et al., 1985). The dissociation constant used for indo- 1 was $250 \mathrm{~nm}$ and $\beta$ was the ratio of the emitted fluorescence at $495 \mathrm{~nm}$ in the absence and presence of calcium. $R_{\min }, R_{\max }$, and $\beta$ were determined in ionomycinpermeabilized cells in $\mathrm{Ca}^{2+}$-free buffer ( 1 mM EGTA) and saturating $\mathrm{Ca}^{2+}\left(10 \mathrm{mM} \mathrm{Ca}^{2+}\right)$. The system was recalibrated following any adjustments. Values of $R_{\min }, R_{\max }$, and $\beta$ ranged from 0.95 to $0.97,8.9$ to 9.1 , and 2.9 to 3.8 respectively.

$\left[\mathrm{II}^{+}\right]_{\mathrm{i}}$ measurement. Measurement of $\left[\mathrm{H}^{+}\right]_{i}$ was accomplished in essentially the same manner as $\left[\mathrm{Ca}^{2+}\right]_{i}$ measurement. Cells were incubated in $1 \mu \mathrm{M}$ carboxy-SNARF-1 acetoxymethyl ester (Molecular Probes, Inc.) for $30 \mathrm{~min}$ and washed for $15 \mathrm{~min}$ in HHSS. Excitation light was 534 $\pm 10 \mathrm{~nm}$ and emitted fluorescence was measured at $580 \pm 10 \mathrm{~nm}$ and $640 \pm 40 \mathrm{~nm}$. Calibration was accomplished using nigericin to permeabilize the cells to $\mathrm{H}^{+}$in HHSS at $\mathrm{pH} 5.0$ and $\mathrm{pH} 8.3$. The $\mathrm{p} K_{\mathrm{a}}$ used for carboxy-SNARF was 7.6. Values of $R_{\min }, R_{\max }$, and $\beta$ ranged from 0.38 to $0.56,2.2$ to 2.4 , and 1.2 to 2.1 , respectively.

Data are presented as mean \pm SEM. Where appropriate, Student's $t$ test was used to determine statistical significance.

\section{Results}

Depolarization of single DRG neurons by superfusion with 50 $\mathrm{mM} \mathrm{K} \mathrm{K}^{+}$for $30 \mathrm{sec}$ activated voltage-sensitive $\mathrm{Ca}^{2+}$ channels increasing $\left[\mathrm{Ca}^{2+}\right]_{i}$ from $94 \pm 11 \mathrm{nM}$ to $1222 \pm 112 \mathrm{nM}(n=14)$ (Fig. $1 A$ ). Recovery to basal $\left[\mathrm{Ca}^{2+}\right]_{i}$ consisted of three distinct phases including a rapid decrease in $\left[\mathrm{Ca}^{2+}\right]_{i}$, a prominent plateau (544 $\pm 50 \mathrm{~nm}$ ) that was maintained for 2-8 min, and finally a slow return to baseline. In parallel experiments, $\left[\mathrm{H}^{+}\right]$, was measured with carboxy-SNARF and found to increase from $74 \pm$ $3 \mathrm{nM}\left(\mathrm{pH}_{i}=7.13\right)$ to $107 \pm 8 \mathrm{nM}\left(\mathrm{pH}_{i}=6.97\right)$ following a 30 sec superfusion with $50 \mathrm{~mm} \mathrm{~K}^{+}(n=12)$ (Fig. $\left.1 B\right)$. The time course of the $\left[\mathrm{H}^{+}\right]_{i}$ increase was similar to that of the plateau phase of the $\left[\mathrm{Ca}^{2+}\right]_{i}$ transient in these cells. Under normal circumstances $\mathrm{H}^{+}$is pumped out of mitochondria by electron transport and reenters the mitochondria to generate ATP. We suggest that large $\mathrm{Ca}^{2+}$ loads are rapidly taken up by mitochondria in these cells and slowly released into the cytosol, giving rise to the plateau in $\left[\mathrm{Ca}^{2+}\right]_{i}$ (see also Thayer and Miller, 1990). The $\left[\mathrm{H}^{+}\right]$, rise following depolarization described here is consistent with the hypothesis that $\mathrm{Ca}^{2+}$ sequestration into mitochondria occurs in lieu of $\mathrm{H}^{+}$transport via the ATP synthase.

To test this hypothesis, we determined the effects of drugs known to disrupt mitochondrial function. Antimycin Al is an antibiotic that blocks the transfer of electrons from cytochrome $b$ to cytochrome $c_{1}$ and thus inhibits the mitochondrial respiratory chain (Slater, 1973). Antimycin is essentially irreversible (Slater, 1973). When depolarized in the presence of $1 \mu \mathrm{M}$ antimycin $\mathrm{A} 1$, the peak amplitude of the $\left[\mathrm{Ca}^{2+}\right]_{i}$ transient increased by $40 \pm 20 \%(N=4)$, but this incrcase was not statistically significant. The rapid buffering and plateau phases of the $\left[\mathrm{Ca}^{2+}\right]$, transient were abolished, making the duration of the $\left[\mathrm{Ca}^{2+}\right]_{i}$ transient shorter $(p<0.05$; Figure $2 A)$. In Figure $2 B$, application of $1 \mu \mathrm{M}$ carbonyl cyanide chlorophenyl hydrazone (CCCP) during the plateau phase produced a large increase in $\left[\mathrm{Ca}^{2+}\right]_{l}$, whereas application of CCCP to cells at rest produced only a modest increase in [ $\left.\mathrm{Ca}^{2 !}\right]_{i}$ (see Figs. $2 \mathrm{C}, 6 \mathrm{~A}$ ). CCCP is a lipophilic weak acid that uncouples mitochondria by dissipating the $\mathrm{H}^{+}$gradient 


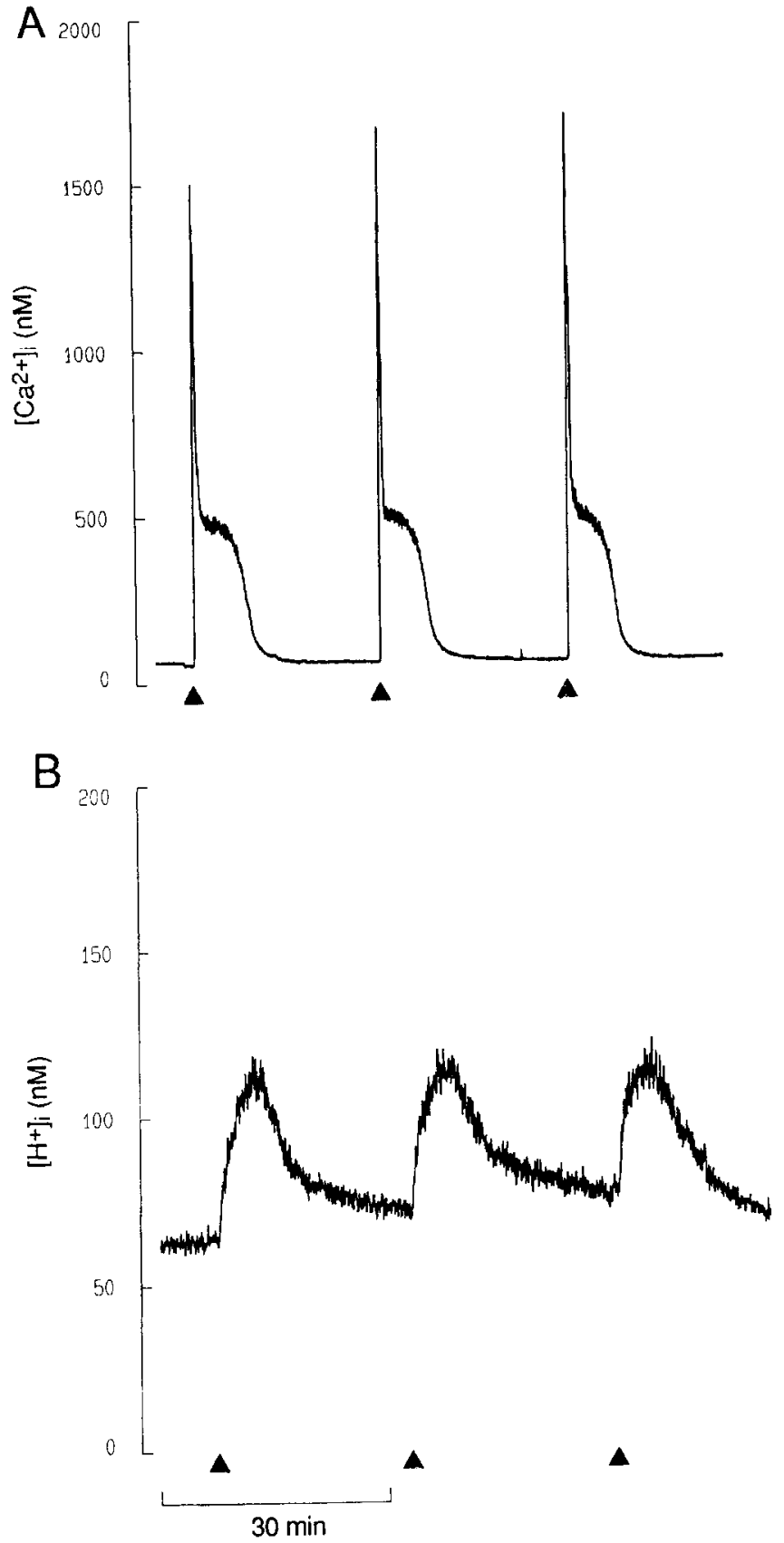

Figure 1. Depolarization-induced increases in $\left[\mathrm{Ca}^{2+}\right]_{1}$ and $\left[\mathrm{H}^{+}\right]_{i}$. Single DRG neurons were depolarized for $30 \mathrm{sec}$ by superfusion with $50 \mathrm{~mm}$ $\mathrm{K}^{+}$at the times indicated by the triangles. $A$, Representative recording shows the pronounced plateau phase characteristic of depolarizationinduced $\left[\mathrm{Ca}^{2}+\right]$, transients in sensory neurons $(N=14)$. $B$, Representative trace shows increase in $\left[\mathrm{H}^{+}\right]$, recorded from a different $\mathrm{DRG}$ neuron following the same depolarizing stimulus as in $A$. The time bar in $B$ refers to both traces.
A

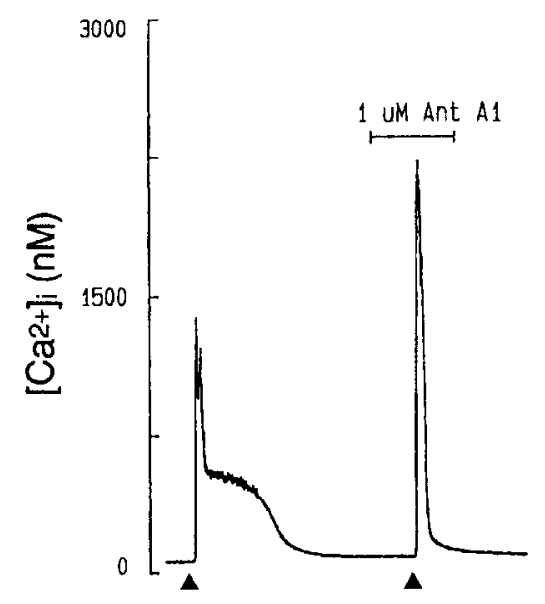

B
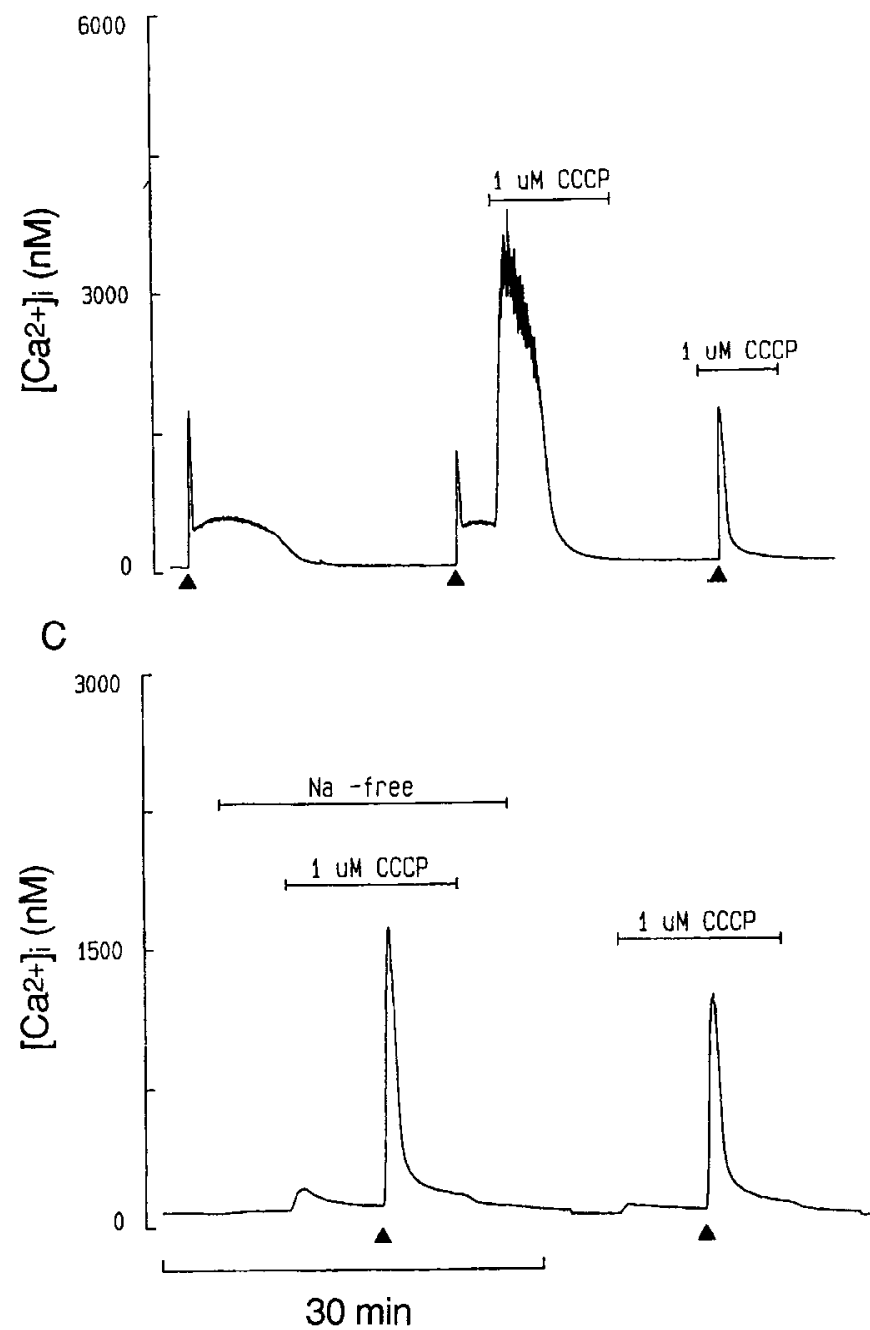

CCCP, applied during the plateau phase of the $\left[\mathrm{Ca}^{2}{ }^{+}\right]_{i}$ transient, evokes a large increase in $\left[\mathrm{Ca}^{2+}\right]$, and that the $\left[\mathrm{Ca}^{2+}\right]$, transient evoked in the presence of $1 \mu \mathrm{M}$ CCCP lacks the plateau phase. $C$, Depolarizationinduced $\left[\mathrm{Ca}^{2+}\right]_{i}$ transients were elicited in the presence of CCCP $(1 \mu \mathrm{M})$. Substituting $N$-methyl-D-glucamine for extracellular $\mathrm{Na}^{+}$did not affect the rate of recovery to basal $\left[\mathrm{Ca}^{2+}\right]_{l}$. The slight decrease in the amplitude of the second response resulted from rundown and was not $\mathrm{Na}^{+}$dependent. Labeled bars indicate treatments, and the time bar in $C$ refers to all three recordings.
Figure 2. Mitochondrial inhibitors block the plateau phase of depolarization-induced $\left[\mathrm{Ca}^{2}\right]$ ] transients. Single DRG neurons were depolarized for $30 \mathrm{sec}$ by superfusion with $50 \mathrm{~mm} \mathrm{~K}+$ at the times indicated by the triangles. $A$, Representative experimental trace shows that $1 \mu \mathrm{M}$ antimycin $A 1$ eliminates the plateau phase of the $\left[\mathrm{Ca}^{2+}\right]_{i}$ transient evoked by $50 \mathrm{~mm} \mathrm{~K}^{+}$. B, Representative experimental trace shows that $1 \mu \mathrm{M}$ 


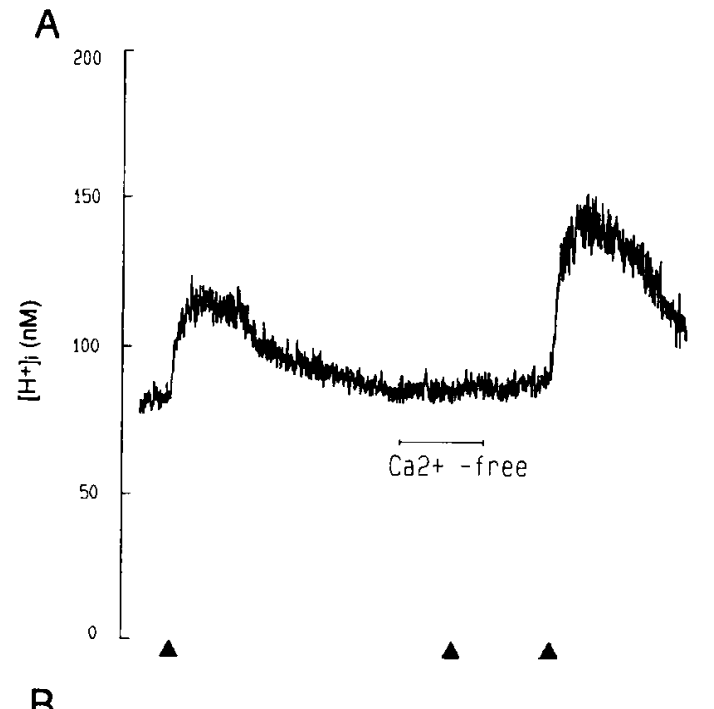

B
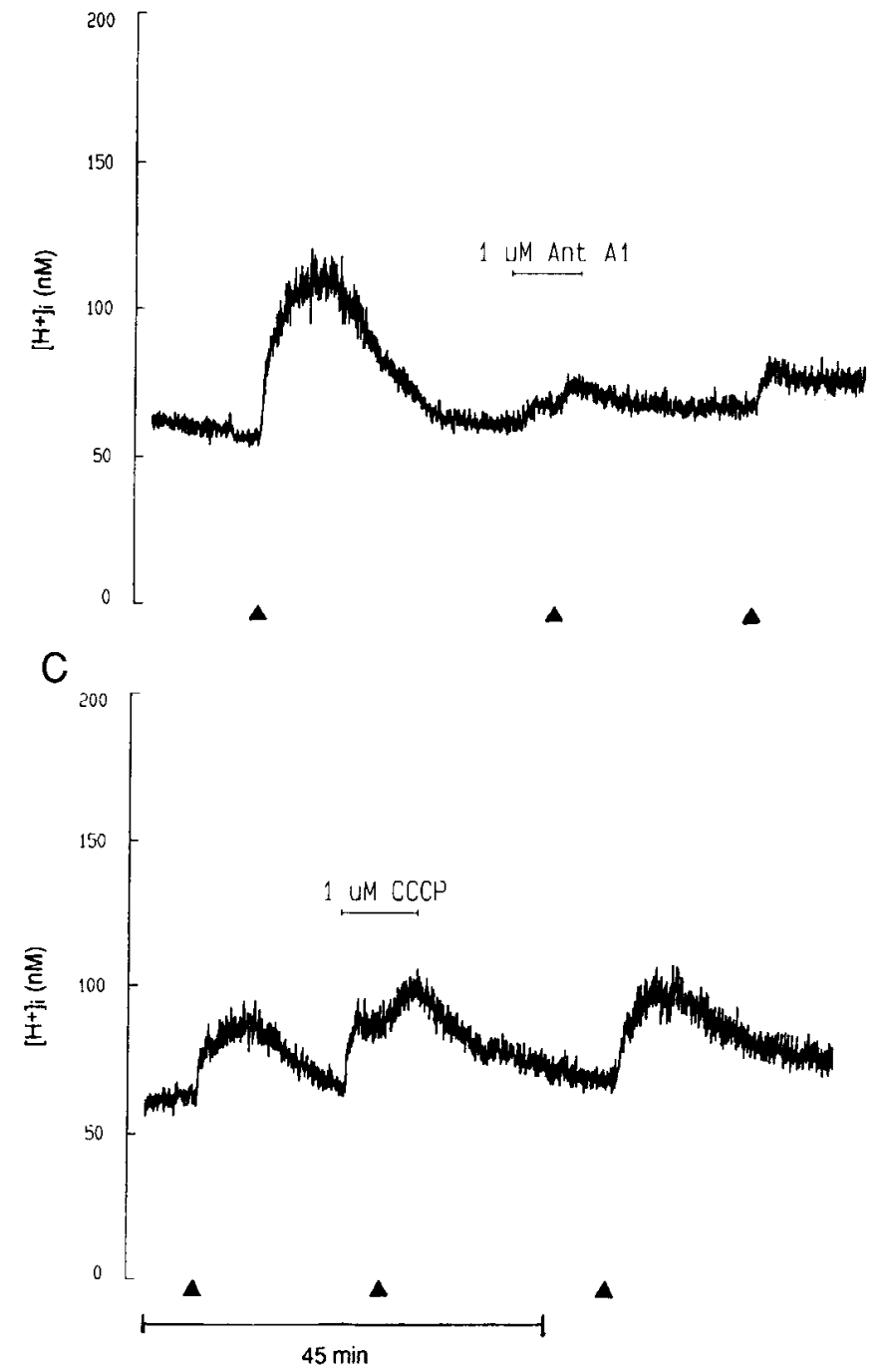

Figure 3. Depolarization-induced rise in $\left[\mathrm{H}^{+}\right]_{i}$, requires extracellular $\mathrm{Ca}^{2+}$ and is blocked by mitochondrial inhibitors. Single DRG neurons were depolarized by $30 \mathrm{sec}$ of superfusion with $50 \mathrm{mM} \mathrm{K}^{+}$at the times indicated by the triangles. $A$, Representative experimental trace shows that the depolarization-induced $\left[\mathrm{H}^{+}\right]$, response requires $\mathrm{Ca}^{2+}$ influx. $B$, Representative experimental trace shows inhibition of $\left[\mathrm{H}^{+}\right]_{\text {increase }}$ following treatment with $1 \mu \mathrm{M}$ antimycin $\mathrm{Al}$ as indicated by horizontal bar. Note that antimycin Al itself increased $\left[\mathrm{H}^{+}\right]$, and, following wash- across the inner mitochondrial membrane and releasing any sequestered $\mathrm{Ca}^{2+}$. Thus, at rest, little $\mathrm{Ca}^{2+}$ is stored in mitochondria but, after intense stimulation, a large amount of $\mathrm{Ca}^{2+}$ is stored within the mitochondria; this stored $\mathrm{Ca}^{2+}$ is released slowly during the plateau phase of the $\left[\mathrm{Ca}^{2+}\right]$ transient. These data are consistent with the idea that the height of the plateau of the $\left[\mathrm{Ca}^{2+}\right]_{i}$ transient corresponds to the mitochondrial set point, and thus, during the plateau phase the mitochondria contain a significant amount of $\mathrm{Ca}^{2+}$. Similar to $\left[\mathrm{Ca}^{2+}\right]_{i}$ transients elicited in antimycin A1, those elicited in the presence of CCCP were slightly greater in amplitude $(23 \pm 13 \%$ increase, $N=6$, $\mathrm{NS}$ ) and the recovery lacked the plateau phase resulting in shorter $\left[\mathrm{Ca}^{2+}\right]_{i}$ transients $(p<0.005)$. In Figure $2 C$, depolarizationinduced transients were elicited in the presence of CCCP and thus lacked the mitochondrial-dependent plateau phase. Removing extracellular $\mathrm{Na}^{+}$had no effect on the rate of recovery to basal $\left[\mathrm{Ca}^{2+}\right]_{i}(N=4)$, suggesting that $\mathrm{Na} / \mathrm{Ca}$ exchange was not important in this process. These experiments were conducted in the presence of CCCP because the removal of $\mathrm{Ca}^{2+}$ from mitochondria is carried out predominantly by $\mathrm{Na} / \mathrm{Ca}$ exchange. Thus, removal of extracellular $\mathrm{Na}^{+}$, which presumably decreases intracellular $\mathrm{Na}^{+}$as well, alters the mitochondrialmediated plateau phase of the $\left[\mathrm{Ca}^{2+}\right]_{i}$ transient (Thayer and Miller, 1990). These data suggest that $\mathrm{Ca}^{2+}$ was buffered by ATP-dependent efflux and sequestration, indicating that during a brief exposure to the uncoupler, ATP levels were maintained, presumably by glycolysis.

The rise in $\left[\mathrm{H}^{+}\right]$, elicited by superfusion with $50 \mathrm{~mm} \mathrm{~K}^{+}$ required extracellular $\mathrm{Ca}^{2+}$, consistent with the idea that the rise in $\left[\mathrm{H}^{+}\right]_{i}$ was secondary to an increase in $\left[\mathrm{Ca}^{2+}\right]_{i}$ (Fig. 3A). Furthermore, $1 \mu \mathrm{M}$ antimycin $\mathrm{A} 1$ inhibited the rise in $\left[\mathrm{H}^{+}\right]_{i}$ by $67 \pm 7 \%(N=4, p<0.05$ by paired $t$ test $)$ and $1 \mu \mathrm{M}$ CCCP inhibited this response by $69 \pm 2 \%(N=4, p<0.05$ by paired $t$ test) (Fig. $3 B, C$ ). Both of these agents increased the basal $\left[\mathrm{H}^{+}\right]_{i}$. The modest rise produced by antimycin $\mathrm{Al}$ may result from stimulation of glycolysis and subsequent accumulation of acidic metabolites. The larger $\left[\mathrm{H}^{+}\right]$increase induced by CCCP probably results from equilibration of acidic organelles with the cytoplasm. These findings suggest that the plateau phase of the $\left[\mathrm{Ca}^{2+}\right]$, transient results from mitochondrial $\mathrm{Ca}^{2+}$ cycling, which effectively uncouples electron transport from ATP synthesis, resulting in $\mathrm{H}^{+}$accumulation in the cytoplasm.

Mitochondria have been shown previously to buffer large $\mathrm{Ca}^{2+}$ loads in DRG neurons (Thayer and Miller, 1990). However, it is unclear whether mitochondria are involved in buffering more physiological $\left[\mathrm{Ca}^{2+}\right]_{i}$ loads. To address this question, trains of action potentials were clicited by clectrical ficld stimulation and the resulting $\left[\mathrm{Ca}^{2+}\right]_{i}$ transients monitored. Passing current (1 msec pulses delivered at $10 \mathrm{~Hz}$ ) between platinum electrodes mounted in the perfusion chamber evoked action potentials. The $\left[\mathrm{Ca}^{2+}\right]_{i}$ transients evoked by field stimulation were blocked by the $\mathrm{Na}^{+}$channel blocker TTX (1 $\left.\mu \mathrm{M}\right)$ (Fig. 4), and the amplitude of these responses displayed an all-or-none relationship to voltage (Piser and Thayer, 1991). The gradual recovery of

out of the drug, the response was still inhibited. $C$, Representative experimental trace shows $\left[\mathrm{H}^{+}\right]$, response was inhibited in the presence of $1 \mu \mathrm{M}$ CCCP. Note that CCCP produced a significant increase in $\left[\mathrm{H}^{+}\right]_{i}$ and that subsequent depolarization produced a reduced net increase in $\left[\mathrm{H}^{+}\right]_{i}$. Treatments are indicated by labeled bars, and the time bar in $C$ refers to all traces. 


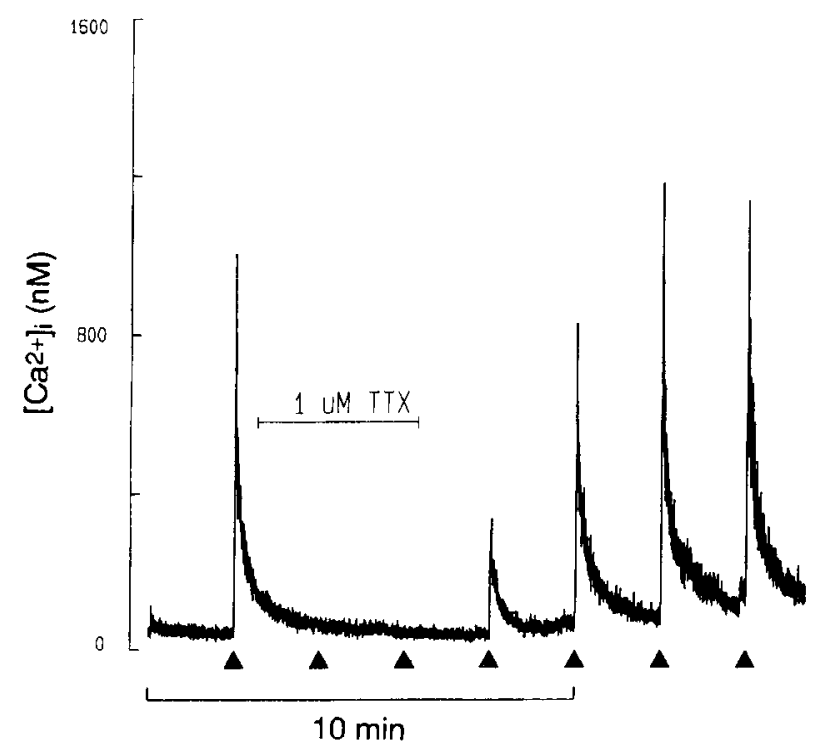

Figure 4. $\quad\left[\mathrm{Ca}^{2+}\right]_{i}$ transients elicited by field potential stimulation are mediated by action potentials. Representative experimental trace shows complete block of $\left[\mathrm{Ca}^{2+}\right]_{i}$ transients elicited by field potential stimulation by $1 \mu \mathrm{M}$ tetrodotoxin. The trace is representative of three experiments. Each $\left[\mathrm{Ca}^{2+}\right]_{i}$ transient resulted from a train of $10,1 \mathrm{msec}$ pulses $(10 \mathrm{~Hz})$ delivered at the times indicated by the triangles.

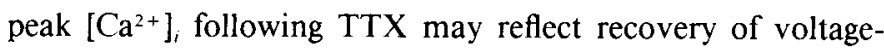
sensitive $\mathrm{Na}^{+}$channels as TTX washes out of the bath. Previously, rat DRG neurons grown in culture were shown to fire action potentials at rates well over $10 \mathrm{~Hz}$ (Neering and McBurney, 1984; Thayer and Miller, 1990). In response to sensory organ stimulation, mammalian sensory neurons in vivo have been shown to discharge at rates exceeding $50 \mathrm{~Hz}$ (Belmonte and Gallego, 1983).

Ten action potentials $(10 \mathrm{~Hz})$, elicited by electrical field stimulation, increased $\left[\mathrm{Ca}^{2+}\right]_{i}$ from $98 \pm 6 \mathrm{~nm}$ to $393 \pm 27 \mathrm{~nm}(n$ $=15$ ) (Fig. 5). The recovery to basal $\left[\mathrm{Ca}^{2+}\right]_{i}$ was described well by a single exponential corresponding to the slow, $\mathrm{Na}^{+}$-independent phase described in Figure $2 C$. The time constant for recovery $(\tau)$ ranged from 7 to $20 \mathrm{sec}$ and varied between cells but was consistent for a given cell. When the train length was increased to $25-30$ action potentials, a plateau phase $(468 \pm 40$ $\mathrm{nM})$, characteristic of the $50 \mathrm{mM} \mathrm{K} \mathrm{K}^{+}$-induced $\left[\mathrm{Ca}^{2+}\right]_{i}$ transients, became apparent (Fig. 5). The recovery consisted of a rapid initial phase ( $\tau \leq 2 \mathrm{sec}$ ), a plateau, and a slow phase $(\tau=8-50$ $\mathrm{sec})$. Thus, as the number of evoked action potentials is increased, the response amplitude increases initially and $\mathrm{Ca}^{2+}$ buffering kinetics are unchanged. Following larger $\mathrm{Ca}^{2+}$ loads, elicited by 15-20 action potentials in the case of the cell in Figure 5, the amplitude remains constant and the duration of the plateau phase increases progressively with increasing number of action potentials.

In Figure 6, the three recovery phases of action potentialevoked $\left[\mathrm{Ca}^{2+}\right]_{i}$ transients are characterized in a single cell. A small $\mathrm{Ca}^{2+}$ load was elicited by a train of 10 action potentials, increasing $\left[\mathrm{Ca}^{2+}\right]_{i}$ to a peak of $336 \mathrm{nM}$, which recovered to basal levels $(70 \mathrm{nM})$ by an exponential process $(\tau=8.5 \mathrm{sec})$ (Fig. 6 , trace 1). A train of 50 action potentials increased $\left[\mathrm{Ca}^{2+}\right]_{i}$ to 535 nM (trace 2). Recovery from this larger $\mathrm{Ca}^{2+}$ load was composed of three phases, an initial rapid phase fit well by a single exponent $(\tau=0.8 \mathrm{sec})$, followed by a plateau at $340 \mathrm{~nm}$, and finally a slow recovery to a slightly elevated resting level. Treatment with the mitochondrial uncoupler CCCP $(1 \mu \mathrm{M})$ produced a transient increase in $\left[\mathrm{Ca}^{2+}\right]_{i}$, presumably due to release of residual $\mathrm{Ca}^{2+}$ stored in mitochondria. In the presence of CCCP a train of 50 action potentials produced a larger peak increase in $\left[\mathrm{Ca}^{2+}\right]_{i}(773$ $\mathrm{nM})$, but this $\left[\mathrm{Ca}^{2+}\right]_{i}$ transient lacked the rapid initial recovery and sustained plateau. The $\left[\mathrm{Ca}^{2+}\right]_{i}$ now recovered by a single exponential process $(\tau=8.6 \mathrm{sec})$ (trace 3$)$. The rate of recovery from the small $\mathrm{Ca}^{2+}$ load produced by 10 action potentials in CCCP was similar to control $(\tau=6.2 \mathrm{sec})$ (trace 4$)$. Note that recovery from small $\mathrm{Ca}^{2+}$ loads and large $\mathrm{Ca}^{2+}$ loads in the presence of CCCP followed similar kinetics. In contrast, when mitochondrial function was not disturbed, large $\mathrm{Ca}^{2+}$ loads were initially buffered at a ten-fold faster rate to a plateau level where $\left[\mathrm{Ca}^{3+}\right]_{i}$ remained until the slower, $\mathrm{Na}^{+}$-independent, nonmitochondrial $\mathrm{Ca}^{2+}$ buffering process removed the $\mathrm{Ca}^{2+}$ from the cytoplasmic and mitochondrial pools. This high-affinity, lowcapacity $\mathrm{Ca}^{2+}$ buffering mechanism is presumably ATP-dependent efflux and/or sequestration. The results described in Figure 6 are representative of three replicates and were also seen when $1 \mu \mathrm{M}$ antimycin A1 was used in place of CCCP $(N=3)$.

\section{Discussion}

Under normal (i.e., resting) circumstances, $\mathbf{H}^{+}$is pumped out of the mitochondria by electron transport and reenters through the ATP synthase to generate ATP. These results suggest that when challenged with large $\left[\mathrm{Ca}^{2+}\right]_{i}$ loads, mitochondria accumulate $\mathrm{Ca}^{2+}$ in lieu of protons, uncoupling electron transport from ATP synthesis. The electron transport chain pumps $\mathrm{H}^{+}$ out, across the inner mitochondrial membrane in order to maintain the electrical gradient across the inner membranc. When $\mathrm{Ca}^{2+}$ enters the mitochondria via the uniporter instead of $\mathrm{H}^{+}$ via the ATP synthase, an acidification of the cytoplasm results. A corresponding ATP depletion may occur, though the ability of glycolysis to compensate is not clear. As other $\mathrm{Ca}^{2+}$ efflux and sequestration processes reduce the cellular $\mathrm{Ca}^{2+} \operatorname{load},\left[\mathrm{Ca}^{2+}\right]_{i}$ decreases and the mitochondria slowly release $\mathrm{Ca}^{2+}$ into the cytoplasm, resulting in the plateau phase. Eventually $\mathrm{Ca}^{2+}$ is removed from the mitochondria and subsequently the cytoplasm, presumably by ATP-dependent efflux or sequestration (Benham et al., 1992).

In these experiments we did not observe any contribution of $\mathrm{Na} / \mathrm{Ca}$ exchange to $\mathrm{Ca}^{2+}$ buffering. However, our recordings were from the cell bodies of DRG neurons, and recent evidence suggests preferential localization of the $\mathrm{Na} / \mathrm{Ca}$ exchanger to nerve terminals (Luther et al., 1992). Thus, in DRG somata, mitochondria, and $\mathrm{Ca}^{2+}$ ATPases are the dominant $\mathrm{Ca}^{2+}$ buffering mechanisms.

The drugs used to disrupt mitochondrial function could potentially affect other cellular processes. Recent reports have demonstrated that nonmitochondrial $\mathrm{Ca}^{2}+$ pools can be disrupted by carbonyl cyanide trifluoromethoxyphenyl hydrazon (FCCP), an analog of CCCP (Jensen and Rehder, 1991; Ruben et al., 1991). In Ilelisoma neurons, FCCP induced a rise in $\left[\mathrm{Ca}^{2+}\right]_{i}$ that persisted indefinitely and was unaffected by prior depletion of mitochondrial $\mathrm{Ca}^{2+}$ stores (Jensen and Rehder, 1991). In contrast, the response we observed to CCCP was transient in nature; when CCCP was applied to resting cells, we saw a slight rise in $\left[\mathrm{Ca}^{2+}\right]_{i}$ that declined back to basal $\left[\mathrm{Ca}^{2+}\right]_{i}$ in the continued presence of the uncoupler (Figs. $2 \mathrm{C}, 6 \mathrm{~A}$ ), suggesting that at rest mitochondria contain little $\mathrm{Ca}^{2+}$. CCCP applied during the plateau phase of $50 \mathrm{~mm} \mathrm{~K} \mathrm{~K}^{+}$-induced $\left[\mathrm{Ca}^{2+}\right]_{i}$ tran- 

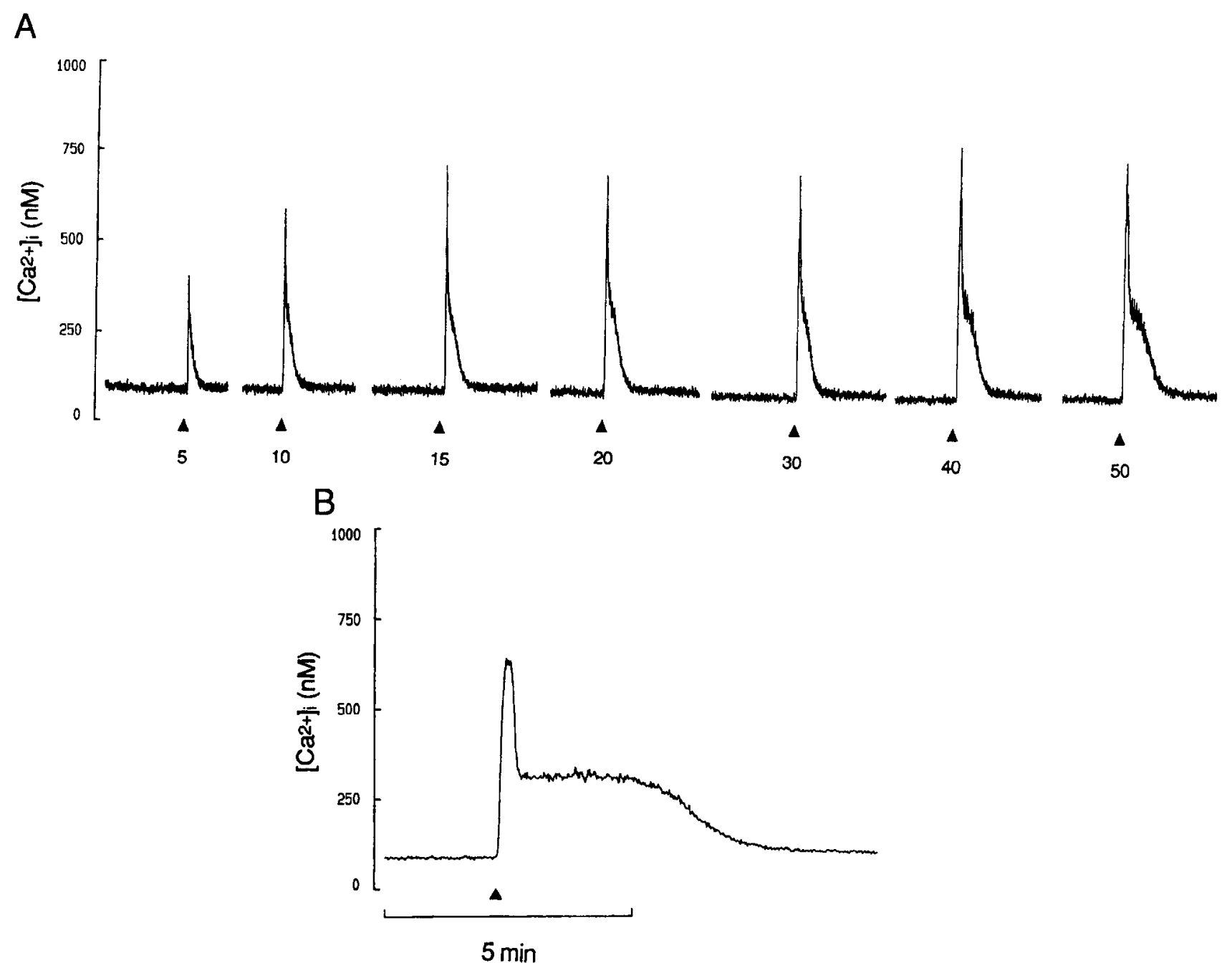

Figure 5. Trains of action potentials elicit $\left[\mathrm{Ca}^{2+}\right]_{i}$ transients with a mitochondrial-mediated plateau phase. $A$, Representative experimental traces

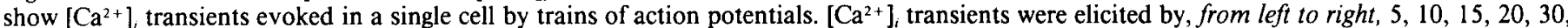
40 , and 50 action potentials. $B$, Superfusion of the same cell for $30 \mathrm{sec}$ with $50 \mathrm{~mm} \mathrm{~K} \mathrm{~K}^{+}$(triangle) elicited a [Ca $\left.{ }^{2+}\right]_{i}$ transient with a pronounced plateau with the same amplitude as that elicited by trains of action potentials in $A$. Progressive development of a plateau phase with action potential bursts of increasing duration was observed in 11 of 16 cells.

sients produced a large increase in $\left[\mathrm{Ca}^{2+}\right]$, followed by a return to baseline while the uncoupler was still present (Fig. $2 B$ ). Thus, during intense stimulation, mitochondria contain significant amounts of $\mathrm{Ca}^{2+}$ that is slowly released during the plateau phase. Additionally, antimycin A1, which inhibits mitochondrial respiration by blocking electron transport, produced similar results, indicating that in our experiments $\mathrm{CCCP}$ exerted its effect through disruption of mitochondrial function. Temporary loss of mitochondrial function could affect $\left[\mathrm{Ca}^{2+}\right]_{i}$ homeostasis through a drop in cellular ATP levels. However, $\mathrm{Ca}^{2+}$ influx through voltage-gated $\mathrm{Ca}^{2+}$ channels, which may require phosphorylation for optimal function, was not significantly impaired since peak $\left[\mathrm{Ca}^{2+}\right]_{i}$ actually increased when the mitochondria were poisoned (Figs. $2 A, B ; 6$ ). Furthermore, $\mathrm{Ca}^{2+}$ efflux from these cells is carried out primarily by $\mathrm{Ca}^{2+}$ ATPases (Benham et al., 1992). Thus, buffering would be slowed by a drop in ATP but $\mathrm{Ca}^{2+}$ buffering kinetics for small $\mathrm{Ca}^{2+}$ loads remained unchanged after CCCP treatment (Fig. 6). Cultured cells are known to have robust glycolytic metabolism that may be able to compensate for a loss of mitochondrial function in our experiments (McConnell et al., 1992).
The mitochondrial contribution to $\mathrm{Ca}^{2+}$ buffering in DRG neurons clearly affects the shape of the $\left[\mathrm{Ca}^{2+}\right]_{i}$ transient, potentially exerting a major role in how different patterns of electrical activity are transduced into biochemical events mediated by changes in $\left[\mathrm{Ca}^{2+}\right]_{i}$. Mitochondria buffer large $\mathrm{Ca}^{2+}$ loads with a corresponding increase in the duration of the $\left[\mathrm{Ca}^{2+}\right]_{i}$ transient; amplitude of the $\left[\mathrm{Ca}^{2+}\right]_{i}$ signal is traded for duration. Increasing the duration of $\left[\mathrm{Ca}^{2+}\right]_{i}$ transients may influence a number of intracellular signaling processes. For example, conversion of $\mathrm{Ca}^{2+}$ calmodulin-dependent protein kinase to its high-affinity prolonged activation state would be expected to be more pronounced following prolonged exposure to elevated $\left[\mathrm{Ca}^{2+}\right]_{i}$ than to brief exposure of greater amplitude (Meyer et al., 1992). Activation of specific transcriptional events mediated by increases in $\left[\mathrm{Ca}^{2+}\right]_{i}$ may be enhanced by a lengthened $\left[\mathrm{Ca}^{3+}\right]_{i}$ transient (Morgan and Curran, 1988). Similarly, $\mathrm{Ca}^{2+}$-activated $\mathrm{K}^{+}$channels and $\mathrm{Ca}^{2+}$-dependent inactivation of $\mathrm{Ca}^{2+}$ current would likely be influenced by a lengthened $\left[\mathrm{Ca}^{2+}\right]_{i}$ transient (Eckert and Chad, 1984; Kohr and Mody, 1991). Following treatment with $2.5 \mu \mathrm{M}$ CCCP, $\mathrm{Ca}^{2+}$-activated $\mathrm{K}^{+}$current was enhanced in molluscan neurons while the decline of this current 


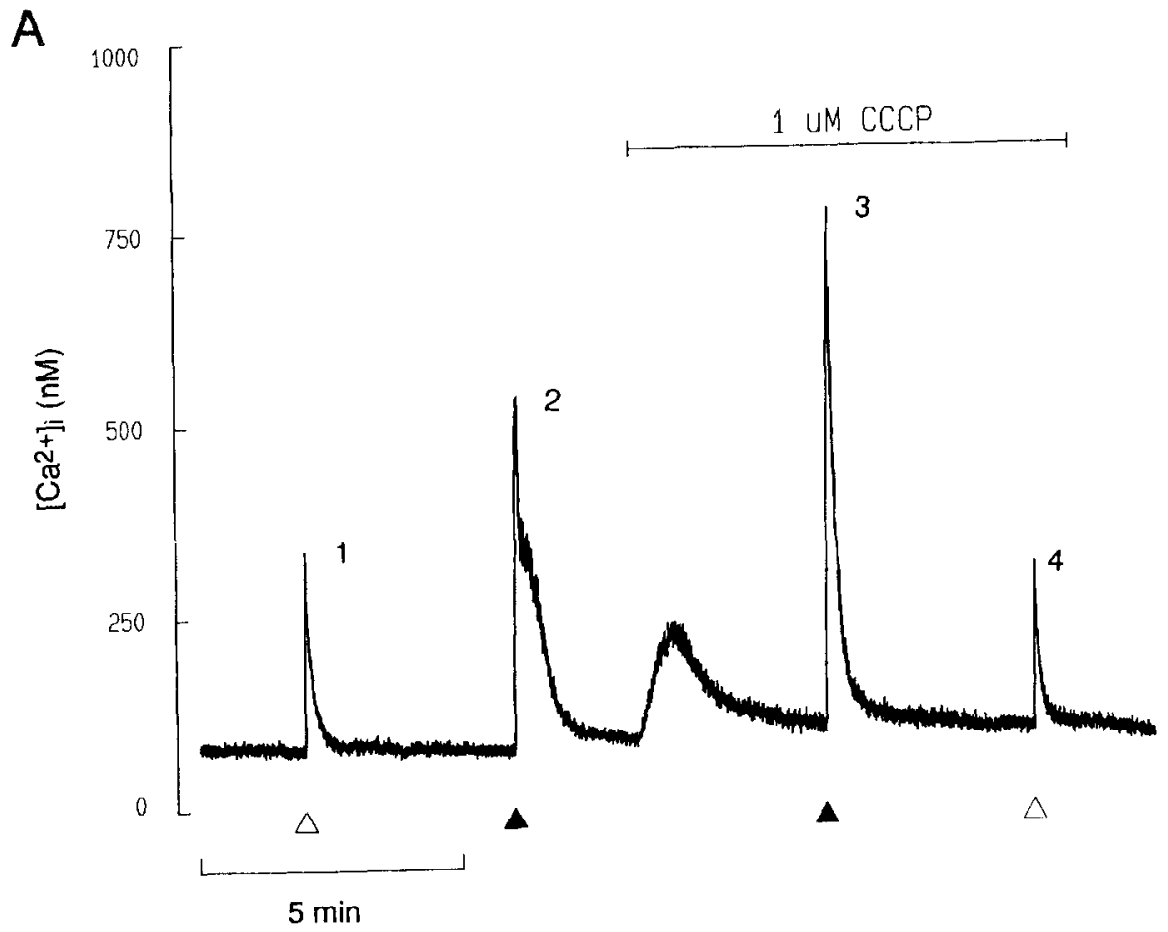

Figure 6. Uncoupling mitochondria alters recovery from large, but not small, action potential-induced $\left[\mathrm{Ca}^{2+}\right]_{i}$ transients. $A$, Experimental trace shows that a $\left[\mathrm{Ca}^{2+}\right]_{\text {i }}$ transient elicited by 10 action potentials (open triangles) was unaffected by $1 \mu \mathrm{M}$ CCCP, while the three phases of the $\left[\mathrm{Ca}^{21}\right]_{i}$ (ransient elicited by 50 action potentials (solid triangles) were reduced to a single phase in the presence of CCCP. $B,\left[\mathrm{Ca}^{2+}\right]_{i}$ transients from $A$ are shown normalized to the same peak height. An exponential curve was fit to the recovery phase of each transient (dashed lines). The time constant of recovery for each transient is shown. Trace 2 is further expanded to show the rapid phase of $\mathrm{Ca}^{2+}$ buffering.
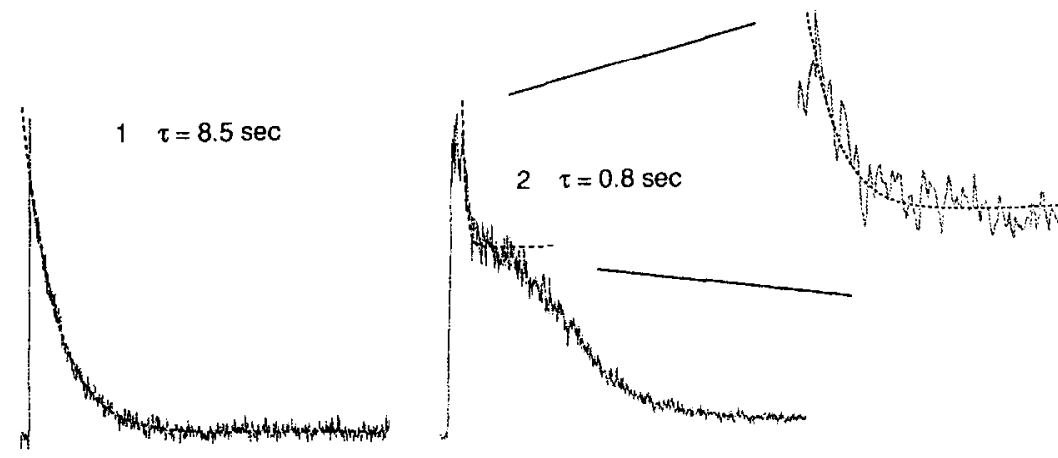

following intracellular injection of $\mathrm{Ca}^{2+}$ was slowed (Barish and Thompson, 1983).

Mitochondrial $\mathrm{Ca}^{2+}$ sequestration may play a protective role as well. $\mathrm{Ca}^{2+}$ overload has been implicated in a number of neurodegenerative disorders, especially those thought to be mediated by excitatory amino acids (Choi, 1987; Randall and Thayer, 1992). Central neurons lacking calcium-binding proteins were shown to deteriorate in response to continuous afferent stimulation (Scharfman and Schwartzkroin, 1989). Intracellular application of calcium chelators protected these neurons from damage. A decrease in mitochondrial $\mathrm{Ca}^{2+}$ buffering might similarly sensitize neurons to $\mathrm{Ca}^{2+}$-mediated toxicity. Indeed, certain neurodegenerative disorders have been linked to maternally inherited mutations of mitochondrial genes (Harding, 1991; Wallace, 1992). We have demonstrated that mitochondria buffer $\mathrm{Ca}^{2+}$ very rapidly, thereby blunting the peak of the depolarization-evoked $\left[\mathrm{Ca}^{2+}\right]_{i}$ transient but lengthening the transient considerably. Thus, the ability to distinguish large $\mathrm{Ca}^{2+}$ loads from small loads is retained while the exposure to high, possibly harmful, $\mathrm{Ca}^{2+}$ levels is limited. 
Acidification of the cytosol following $\mathrm{Ca}^{2+}$ influx has been described previously in molluscan neurons (Meech and Thomas, 1977; Ahmed and Connor, 1980; Meech and Thomas, 1980). A number of processes are modulated in part by $\mathrm{pH}_{i}$. Dissipation of proton gradients leads to release of $\mathrm{Ca}^{2+}$ from intracellular stores (Jensen and Rehder, 1991; Ozawa and Schulz, 1991; Ruben et al., 1991). Changes in $\mathrm{pH}_{i}$ may be important in activating transcription in response to mitogens and growth factors (Ganz et al., 1989). Many transport processes are proton coupled and thus $\mathrm{pH}$ dependent. Of particular importance to neuronal function are neurotransmitter transporters (Bouvier et al., 1992). That $\mathrm{Ca}^{2+}$ overload will trigger neurotoxic processes is clear, whether the marked acidification that accompanies large $\mathrm{Ca}^{2+}$ loads in sensory neurons also contributes to cytotoxicity remains to be determined. In liver cells, acidification of the cytosol was shown to play a protective role (Currin et al., 1991).

Sensory neurons respond to appropriate stimuli with trains of action potentials (Matthews, 1931). In culture, rat DRG neurons are capable of firing action potentials at frequencies greater than $10 \mathrm{~Hz}$ (Neering and McBurney, 1984; Thayer and Miller, 1990). In vivo, trains of action potentials firing at frequencies in excess of $50 \mathrm{~Hz}$ have been recorded from the carotid sinus baroreceptor during mechanical stimulation of the appropriate vessel wall (Belmonte and Gallego, 1983). Clearly, the stimulus intensity at which we observed a mitochondrial contribution to $\mathrm{Ca}^{2+}$ buffering was well within the physiological range.

In conclusion, we have demonstrated that mitochondria can contribute to buffering physiological $\mathrm{Ca}^{2+}$ loads in neurons. $\mathrm{Mi}$ tochondrial $\mathrm{Ca}^{2+}$ buffering alters the profile of action potential induced $\left[\mathrm{Ca}^{2+}\right]_{i}$ transients, potentially influencing $\mathrm{Ca}^{2+}$-mediated intracellular signaling processes. Additionally, the acidification arising from mitochondrial $\mathrm{Ca}^{2+}$ buffering may play a role in signaling processes or influcnce the toxicity that can result from $\mathrm{Ca}^{2+}$ overload. The importance of mitochondrial $\mathrm{Ca}^{2+}$ sequestration to $\mathrm{Ca}^{2+}$ buffering increases relative to other processes as the size of the $\mathrm{Ca}^{2+}$ load increases. While this attribute may be useful in attenuating $\mathrm{Ca}^{2+}$ overload, we have shown that the mitochondrial contribution to $\mathrm{Ca}^{2+}$ buffering is not limited to pathological situations, but rather, plays an important role in shaping physiological $\left[\mathrm{Ca}^{2+}\right]_{i}$ transients.

\section{References}

Ahmed Z, Connor JA (1980) Intracellular $\mathrm{pH}$ changes induced by calcium influx during electrical activity in molluscan neurons. J Gen Physiol 75:403-426.

Baimbridge KG, Celio MR, Rogers JH (1992) Calcium-binding proteins in the nervous system. Trends Neurosci 15:303-307.

Barish ME, Thompson SH (1983) Calcium buffering and slow recovery kinetics of calcium-dependent outward current in molluscan neurones. J Physiol (Lond) 337:201-219.

Belmonte C, Gallego R (1983) Membrane properties of cat sensory neurones with chemoreceptor and baroreceptor endings. J Physiol (Lond) 342:603-614.

Benham CD, Evans ML, Mcbain CJ (1992) $\mathrm{Ca}^{2+}$ efflux mechanisms following dcpolarization evoked calcium transients in cultured rat sensory neurones. J Physiol (Lond) 455:567-583.

Blaustein MP, Goldman WF, Fontana G, Krueger BK, Santiago EM, Steele TD, Weiss DN, Yarowsky PJ (1991) Physiological roles of the sodium-calcium exchanger in nerve and muscle. Ann NY Acad Sci 639:254-274.

Bouvier M, Szatkowski M, Amato A, Atwell D (1992) The glial cell glutamate uptake carrier countertransports $\mathrm{pH}$-changing anions. $\mathrm{Na}-$ ture $360: 471-474$.

Carafoli E (1987) Intracellular calcium homeostasis. Annu Rev Biochem 56:395-433.
Carafoli E (1991) The calcium pumping ATPase of the plasma membrane. Annu Rev Physiol 53:531-547.

Choi DW (1987) Ionic dependence of glutamate neurotoxicity. J Neurosci 7:369-379.

Currin RT, Gores GJ, Thurman RG, Lemasters JJ (1991) Protection by acidotic $\mathrm{pH}$ against anoxic cell killing in perfused rat liver: evidence for a $\mathrm{pH}$ paradox. FASEB J 5:207-210.

Eckert R, Chad JE (1984) Inactivation of Ca channels. Prog Biophys Mol Biol 44:215-267.

Ganz MB, Boyarsky G, Sterzel RB, Boron WF (1989) Arginine vasopressin enhances $\mathrm{pH}_{i}$ regulation in the presence of $\mathrm{HCO}_{3}{ }^{-}$by stimulating three acid-base transport systems. Nature 337:648-651.

Grynkiewicz G, Peonie M, Tsien RY (1985) A new generation of calcium indicators with greatly improved fluorescence properties. J Biol Chem 260:3440-3450.

Gunter TE, Pfeiffer DR (1990) Mechanisms by which mitochondria transport calcium. Am J Physiol 258:C755-C786.

Harding AE (1991) Neurological disease and mitochondrial genes. Trends Neurosci 4:132-138

Henzi V, MacDermott AB (1992) Characteristics and function of $\mathrm{Ca}^{2+}$. and inositol 1,4,5-trisphosphate-releasable stores of $\mathrm{Ca}^{2+}$ in neurons. Neuroscience 46:251-273.

Hess P (1990) Calcium channels in vertebrate cells. Annu Rev Neurosci 13:337-356.

Jensen JR, Rehder V (1991) FCCP releases $\mathrm{Ca}^{2+}$ from a non-mitochondrial store in an identified Helisoma neuron. Brain Res 551:311314.

Jensen JR, Lynch G, Baudry M (1987) Polyamines stimulate mitochondrial calcium transport in rat brain. J Neurochem 48:765-772.

Kohr G, Moody I (1991) Endogenous intracellular calcium buffering and the activation/inactivation of HVA calcium currents in rat dentate gyrus granule cells. J Gen Physiol 98:941-967.

Luther PW, Yip RK, Bloch RJ, Ambesi A, Lindenmayer GE, Blaustein MP (1992) Presynaptic localization of sodium/calcium exchangers in neuromuscular preparations. J Neurosci 12:4898-4904.

Lytton J, Westlin M, Hanley MR (1991) Thapsigargin inhibits the sarcoplasmic or endoplasmic reticulum Ca-ATPase family of calcium pumps. J Biol Chem 266:17067-17071.

MacDermott AB, Mayer ML, Westbrook GL, Smith SJ, Barker JL (1986) NMDA-receptor activation increases cytoplasmic calcium concentration in cultured spinal cord neurones. Nature 321:519-522.

Matthews BHC (1931) The response of a single end organ. J Physiol (Lond) 71:64-110.

McConnell HM, Owicki JC, Parce JW, Miller DL, Baxter GT, Wada HG, Pitchford WS (1992) The cytosensor microphysiometer: biological applications of silicon technology. Science 257:1906-1912.

McCormack JG, Halestra AP, Denton RM (1990) Role of calcium ions in regulation of mammalian intramitochondrial metabolism. Physiol Rev 70:391-425.

Meech RW, Thomas RC (1977) The effect of calcium injection on the intracellular sodium and of $\mathrm{pH}$ of snail neurones. J Physiol (Lond) 265:867-879.

Meech RW, Thomas RC (1980) Effect of measured calcium chloride injections on the membrane potential and internal $\mathrm{pH}$ of snail neurones. J Physiol (Lond) 298:111-129.

Meyer T, Hanson PI, Stryer L, Schulman H (1992) Calmodulin trapping by calcium-calmodulin-dependent protein kinase. Science 256 : 1199-1202.

Miller RJ (1988) Calcium signalling in neurons. Trends Neurosci 11: 415-419.

Miller RJ (1991) The control of neuronal $\mathrm{Ca}^{2+}$ homeostasis. Prog Neurobiol 37:255-285.

Morgan JI, Curran T (1988) Calcium as a modulator of the immediateearly gene cascade in neurons. Cell Calcium 9:303-311.

Neering IR, McBurney RN (1984) Role for microsomal Ca storage in mammalian neurones? Nature 309:158-160.

Nicholls DG (1985) A role for the mitochondrion in the protection of cells against calcium overload? Prog Brain Res 63:97-106.

Ozawa T, Schulz I (1991) $\mathrm{H}^{+}$uptake increase GTP-induced connection of inositol 1,4,5-trisphosphate- and caffeine-sensitive calcium pools in pancreatic microsomal vesicles. Biochem Biophys Res Commun 180:755-764.

Piser TM, Thayer SA (1991) Preferential recruitment of the dihydropyridine-sensitive component of action-potential-induced $\mathrm{Ca}^{2+}$ influx. Soc Neurosci Abstr 17:461.1. 
Randall RD, Thayer SA (1992) Glutamate-induced calcium transient triggers delayed calcium overload and neurotoxicity in rat hippocampal neurons. J Neurosci 12:1882-1895.

Rizzuto R, Simpson AWM, Brini M, Pozzan T (1992) Rapid changes of mitochondrial $\mathrm{Ca}^{2+}$ revealed by specifically targeted recombinant aequorin. Nature 358:325-327.

Rottenberg H, Marbach M (1990) Regulation of $\mathrm{Ca}^{21}$ transport in brain mitochondria. I. The mechanism of spermine enhancement of $\mathrm{Ca}^{2+}$ uptake and retention. Biochim Biophys Acta 1016:77-86.

Ruben L, Hutchinson A, Moehlman J (1991) Calcium homeostasis in trypanosoma brucei. J Biol Chem 266:24351-24358.

Sanchez-Armass S, Blaustein MP (1987) Role of sodium-calcium exchange in regulation of intracellular calcium in nerve terminals. Am J Physiol 252:C595-C603.

Scharfman HE, Schwartzkroin PA (1989) Protection of dentate hilar cells from prolonged stimulation by intracellular calcium chelation. Science 246:257-260.

Sipahimalani AS, Werth JL, Michelson RH, Dutta AK, Efange SMN, Thayer SA (1992) Lipophilic amino alcohols with calcium channel blocking activity. Biochem Pharmacol 44:2039-2046.
Slater EC (1973) The mechanism of action of the respiratory inhibitor, antimycin. Biochim Biophys Acta 301:129-154.

Thayer SA, Miller RJ (1990) Regulation of the free intracellular calcium concentration in rat dorsal root ganglion ncurones in vitro. $\mathrm{J}$ Physiol (Lond) 425:85-115.

Thayer SA, Sturek M, Miller RJ (1988) Measurement of neuronal $\mathrm{Ca}^{2+}$ transients using simultaneous microfluorimetry and electrophysiology. Pfluegers Arch 412:216-223.

Tsien RW (1983) Calcium channels in excitable cell membranes. Annu Rev Physiol 45:341-358.

Wallace DC (1992) Mitochondrial genetics: a paradigm for aging and degenerative diseases? Science 256:628-632.

Weetall HH (1970) Storage stability of water-insoluble enzymes covalently coupled to organic and inorganic carriers. Biochim Biophys Acta 212:1-7.

Werth JL, Thayer SA (1992) Mitochondria buffer physiological calcium loads in rat dorsal root ganglion neurons. Soc Neurosci Abstr 18:341.14. 